\title{
A simplified method for rapid determination of porphyrins by thin-layer chromatography
}

\author{
T. OKUDA, H. NAKAJIMA, K. YATSUKI, M. AMANO, AND G. UMEDA \\ From the Kitakyusyu Research Institute for Environmental Pollution, Kitakyushu, Japan
}

ABSTRACT Free porphyrins, especially copro-, uro-, and protoporphyrin, were successfully separated by talc thin-layer chromatography (TLC), and were determined from the relationship of the weight and the area of porphyrins in the spot on the thin-layer plate. The results obtained from both the solvent extraction and the simple, rapid TLC method reported in this paper showed good correlation for coproporphyrin levels up to $400 \mu \mathrm{g} / \mathrm{l}$. The TLC method was applied to the determination of urinary coproporphyrin in lead workers and in rats.

Porphyrins, which are important intermediate pigments in haem metabolism, have usually been determined by the solvent extraction (SE) method (e.g., Sano and Granick, 1961). However, this method, which is described below, is very complicated and time-consuming, and uses expensive analytical reagents.

With (1969) found that free porphyrins, especially copro- (CP), uro- (UP), and protoporphyrin (PP), could be successfully separated by talc thin-layer chromatography. Purdy and Truter (1962) investigated the relationship between the spot weight and the spot area in thin-layer chromatograms and found that plots of the square root of the spot area versus the logarithm of the weight gave a straight line. We have now found a simplified method (the TLC method) for rapid determination of free porphyrins based on both of the above methods.

The results obtained by the TLC method agreed well with those obtained by the SE method. Our new method was therefore applied to the determination of urinary coproporphyrin in lead workers and in rats.

\section{Materials and methods}

MATERIAL

Urine samples were obtained from lead-exposed workers, 20 from one newspaper company and six from another. In addition, 21 samples from patients who had suffered from Yusho disease (Katsuki,

Received for publication 8 December 1975

Accepted for publication 11 December 1976
1969) caused by contamination of food with polychlorinated biphenyls (PCB), were tested. Six samples were also obtained from a man suspected to have been accidentally exposed to PCB which had leaked from transformers. In these cases, porphyrinuria was suspected because of the symptoms and clinical findings. Ten hospital workers, aged 23-36 years, with no known exposure to lead, were used to provide control urine samples. Urine samples were also obtained from rats. One rat was given a diet fortified with PCB for four months, and was then killed after being starved for 24 hours. The urine, faeces and liver of this rat were used for determination of UP, CP and PP by the TLC method.

\section{ANALYTICAL METHODS}

\section{The TLC method}

A glass plate was dipped in talc-methanol suspension, withdrawn, and air-dried to form a thin layer with a thickness of about $250 \mu \mathrm{m}$. A $20 \mu \mathrm{l}$ quantity of the sample was spotted $2 \mathrm{~cm}$ from the edge of the plate by a microsyringe and dried. The plate was soaked at a depth of $1 \mathrm{~cm}$ in solvent $(0.5 \mathrm{~N}$ (mol/l) $\mathrm{HCl}$ :acetone; $3: 7$ by volume) and developed until the solvent ascended $4 \mathrm{~cm}$ from the starting point. After about $20 \mathrm{~min}$ the region of red fluorescence of porphyrins was marked under u.v. light $(365 \mathrm{~nm})$ in a dark room and the marked area measured by tracing through transparent paper. A calibration curve was made by spotting various concentrations of the porphyrin solutions on to plates. 
The SE method

The solvents used were peroxide-free. Determinations were, for the most part, carried out on urinary porphyrins (CP and UP), but CP and PP in rat faeces and liver were analysed by a very similar procedure.

Determination of $C P$. A separating funnel containing $5-20 \mathrm{ml}$ of urine and $60 \mathrm{ml}$ of the $3: 1$ mixture of ethyl acetate :acetic acid was shaken for $3 \mathrm{~min}$ and then the contents were photo-oxidised under fluorescent light $(40 \mathrm{~W})$ at room temperature for $30 \mathrm{~min}$. Water was separated and the organic layer was washed with two portions of $20 \mathrm{ml}$ of $3 \%$ aqueous sodium acetate. The container was shaken again after the addition of $30 \mathrm{ml}$ of ether. The separated water was again removed and porphyrins were extracted from the organic layer with two portions of 5 and $4 \mathrm{ml}$ of $2.5 \mathrm{~N}(\mathrm{~mol} / \mathrm{l}) \mathrm{HCl}$. The $\mathrm{pH}$ of the aqueous layer was adjusted to 3.5 with saturated aqueous sodium acetate, and porphyrins were again extracted from the aqueous layer with $30 \mathrm{ml}$ of ether. The ether layer was washed with two portions of $10 \mathrm{ml}$ of water, and the porphyrins were reextracted with two portions of 5 and $3.5 \mathrm{ml}$ of $0.1 \mathrm{~N}$ $(\mathrm{mol} / \mathrm{l}) \mathrm{HCl}$. The whole volume was made up to $10 \mathrm{ml}$ by adding $0 \cdot 1 \mathrm{~N} \mathrm{HCl}$. The absorbency of the solution was measured at three wavelengths of 380 , 401 , and $430 \mathrm{~nm}$ by the Hitachi model 139 spectrophotometer. The CP concentration was calculated by the following formula (Rimington, 1960), where $V$ is the volume of urine sampled, $v$ is the final volume of $\mathrm{HCl}$, and $\mathrm{E}$ is the optical density at the wavelength stated:

$$
\left[2 \mathrm{E}_{401}-\left(\mathrm{E}_{380}+\mathrm{E}_{430}\right)\right] \times 730 \times \frac{\mathrm{v}}{\mathrm{V}}=\mu \mathrm{g} \mathrm{CP} / \mathrm{l}
$$

Determination of UP. The water layer separated in the above procedure was collected, adjusted to pH 1.5 with concentrated $\mathrm{HCl}$, and shaken with $50 \mathrm{ml}$ of cyclohexanone for $10 \mathrm{~min}$, and then the mixture was centrifuged $(2700 \mathrm{rev} / \mathrm{min})$ for $15 \mathrm{~min}$. The cyclohexanone layer was separated and UP was extracted with $60 \mathrm{ml}$ of ether and again extracted from the ether layer with two portions of 5 and $4 \mathrm{ml}$ of $1.5 \mathrm{~N} \mathrm{HCl}$. Two extracts were combined and the extract was filtered. The UP concentration was calculated according to the following formula using three absorbencies at 380,405 , and $430 \mathrm{~nm}$ :

$$
\left[2 \mathrm{E}_{405}-\left(\mathrm{E}_{380}+\mathrm{E}_{430}\right)\right] \times 832 \times \frac{\mathrm{v}}{\mathrm{V}}=\mu \mathrm{g} \mathrm{UP} / 1
$$

Determination of PP. From the residual ether layer used in the CP determination, PP was extracted with two portions of 5 and $3 \mathrm{ml}$ of $1.5 \mathrm{~N} \mathrm{HCl}$. The
PP concentration was calculated according to the following formula using three absorbencies at 380 , 406, and $430 \mathrm{~nm}$ :

$$
\left[2 E_{406}-\left(E_{380}+E_{430}\right)\right] \times 1226 \times \frac{v}{V}=\mu g P P / 1
$$

\section{ADSORBENT}

In this experiment talc was employed to separate three porphyrins (CP, UP, and PP), the solvent being $0.5 \mathrm{~N} \mathrm{HCl}$ : acetone. Characteristics of the talc are shown in Table 1.

\section{THICKNESS OF TALC THIN LAYER}

It was very important to form a uniform thin layer in order to obtain good reproducible results, and spots well separated from each other. When a thin layer less than $250 \mu \mathrm{m}$ thick was used, we could not treat many samples at the same time and there was a great deal of delay before developing because drops of the solution diffused and did not dry easily. When a thin layer more than $250 \mu \mathrm{m}$ thick was used, it was found not to be uniform, although the defects mentioned above could be avoided. The most satisfactory thin layer was about $250 \mu \mathrm{m}$ thick.

\section{DEVELOPING SOLVENTS}

A mixture of $0.5 \mathrm{~N} \mathrm{HCl}$ :acetone $(3: 7)$ or $1 \mathrm{~N}$ $\mathrm{HCl}$ :acetone $(2: 8)$ was used as a solvent because the spots were separated well from each other and the developing time was short. When the solvent was rich in acetone, the developing time was reduced and the $\mathrm{Rf}$ value increased although the degrees of separation and distinctness were poor. On the other hand, a great deal of time was required for developing and the $\mathrm{Rf}$ value was reduced when there was little acetone.

\section{Results}

\section{THE RF VALUE OF PORPHYRINS}

Two typical chromatograms of porphyrins in human urine and in a standard solution are shown in Fig. 1. UP, CP, and PP separated well from each other and their $\mathrm{Rf}$ values were about $0 \cdot 7,0 \cdot 3$, and 0 respectively.

RELATIONSHIP BETWEEN THE WEIGHT AND THE AREA OF PORPHYRINS IN THE SPOT The relationship between the weight $(\mathrm{W})$ and the area (A) of porphyrins in the spot gave a gentle curve. We found that plots of the square root of $A$ versus the logarithm of $\mathrm{W}$ of porphyrins in a spot gave a straight line (Fig. 2). As a result, the following 
equation was obtained, where both $a$ and $b$ are constants:

$$
\sqrt{\mathrm{A}}=\mathrm{a} \log \mathrm{W}+\mathrm{b}
$$

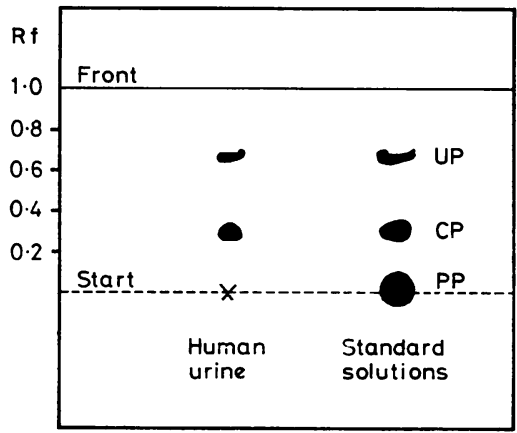

Fig. 1 Typical chromatograms of porphyrins in human urine and in a standard solution.

CALIBRATION CURVE AND REPRODUCIBILITY OF URINARY CP VALUES MEASURED BY THE

TLC METHOD

The calibration curve of $\mathrm{CP}$ in a diluted solution such as human urine is shown in Fig. 3. The reproducibility of urinary $\mathrm{CP}$ values measured by the TLC method is given in Table 2 . The range of the coefficients of variation was $2 \cdot 5-17 \cdot 4 \%$.

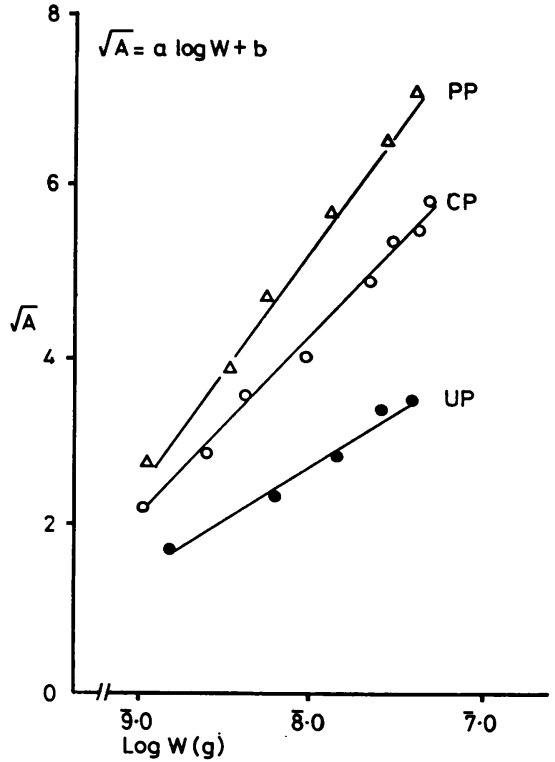

Fig. 2 Plots of $\sqrt{A}$ versus log $W$.

CORRELATION BETWEEN THE SE AND THE TLC METHODS FOR THE DETERMINATION OF CP

$C P$ in human urine $(n=63)$ and in rat urine $(n=25)$

Table 1 Characteristics of talc

\begin{tabular}{|c|c|c|c|c|c|}
\hline Sample & Maker & Colour & Mobility & $\begin{array}{l}\text { Tapping bulk density } \\
(\mathrm{g} / \mathrm{ml})\end{array}$ & $\begin{array}{l}\text { Quality of suspension } \\
\text { with methanol }\end{array}$ \\
\hline $\begin{array}{l}1 \\
2 \\
3 \\
4 \\
5\end{array}$ & $\begin{array}{l}\text { A } \\
\text { B } \\
\text { C } \\
\text { D } \\
\text { E }\end{array}$ & $\begin{array}{l}\text { True white } \\
\text { White } \\
\text { True white } \\
\text { Grey-white } \\
\text { Grey-white }\end{array}$ & $\begin{array}{l}\text { Best } \\
\text { Second-best } \\
\text { Good } \\
\text { Bad } \\
\text { Bad }\end{array}$ & $\begin{array}{l}0.488 \\
0.349 \\
0.388 \\
0.563 \\
0.563\end{array}$ & $\begin{array}{l}\text { good } \\
\text { good } \\
\text { good } \\
\text { bad } \\
\text { bad }\end{array}$ \\
\hline
\end{tabular}

${ }^{1}$ Calculated from the volume of $10 \mathrm{~g}$ of talc placed in a $25 \mathrm{ml}$ measuring cylinder which was then firmly tapped 10 times.

Table 2 Individual differences in urinary CP values measured by the TLC method

\begin{tabular}{|c|c|c|c|c|}
\hline Experimenter & Sample No. & $C P$ values* $(\mu g / l)$ & $M \pm S D \dagger(\mu g / l)$ & $C V \ddagger(\%)$ \\
\hline $\mathbf{A}$ & $\begin{array}{l}1 \\
2 \\
3 \\
4 \\
5\end{array}$ & $\begin{array}{l}95,108,108,95 \\
105,105,95,95,95 \\
85,95,90,90,90 \\
195,180,175,200,180 \\
145,130,130,145,145\end{array}$ & $\begin{array}{r}102 \pm 7 \cdot 5 \\
99 \pm 5 \cdot 5 \\
90 \pm 3 \cdot 5 \\
186 \pm 10 \cdot 8 \\
139 \pm 8 \cdot 2\end{array}$ & $\begin{array}{l}7 \cdot 4 \\
5 \cdot 5 \\
3 \cdot 9 \\
5 \cdot 8 \\
5 \cdot 9\end{array}$ \\
\hline $\mathbf{B}$ & $\begin{array}{l}1 \\
2 \\
3\end{array}$ & $\begin{array}{l}178,173,182,173 \\
200,228,207,207 \\
257,240,240,257,283\end{array}$ & $\begin{array}{l}177 \pm 4 \cdot 4 \\
211 \pm 12 \cdot 1 \\
255 \pm 17 \cdot 6\end{array}$ & $\begin{array}{l}2 \cdot 5 \\
5 \cdot 7 \\
6 \cdot 9\end{array}$ \\
\hline $\begin{array}{l}\text { C } \\
\text { D }\end{array}$ & $\begin{array}{l}1 \\
1 \\
2 \\
3\end{array}$ & $\begin{array}{l}114,114,139,114,85,102 \\
115,104,133,109 \\
164,156,170,190 \\
50,60,73,73\end{array}$ & $\begin{array}{l}111 \pm 17 \cdot 7 \\
115 \pm 12 \cdot 7 \\
170 \pm 14 \cdot 5 \\
64 \pm 11 \cdot 2\end{array}$ & $\begin{array}{r}15 \cdot 9 \\
11 \cdot 0 \\
8 \cdot 5 \\
17 \cdot 4\end{array}$ \\
\hline
\end{tabular}

*Values obtained when $20 \mu \mathrm{l}$ of urine were spotted.

$\dagger$ Mean value \pm standard deviation.

$\ddagger$ Coefficient of variation. 
was determined by the two methods. The correlation between both these methods is shown in Figs. 4 and 5, and Table 3. In Fig. 4 (human urine) the correlation coefficient $(r)$ was $0.77(P<0.01)$ in CP levels up to $350 \mu \mathrm{g} / \mathrm{l}$. In Fig. 5 (rat urine) $\mathrm{r}$ was 0.90 $(\mathrm{P}<0.01)$ in levels up to $400 \mu \mathrm{g} / \mathrm{l}$ and $0.24(\mathrm{P}<0.1)$ in levels above $400 \mu \mathrm{g} / \mathrm{l}$.

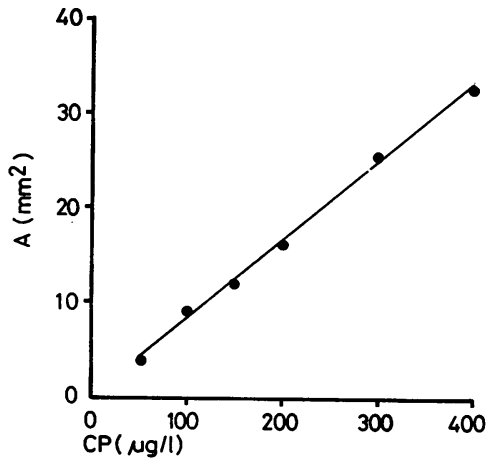

Fig. 3 CP calibration curve (20 $\mu$ l samples spotted $)$.

URINARY CP IN LEAD WORKERS

Urinary CP was determined in urine samples from workers exposed to lead in two newspaper offices, from the other patients described earlier and from 10 control subjects. The results obtained using the SE method are compared with those obtained using

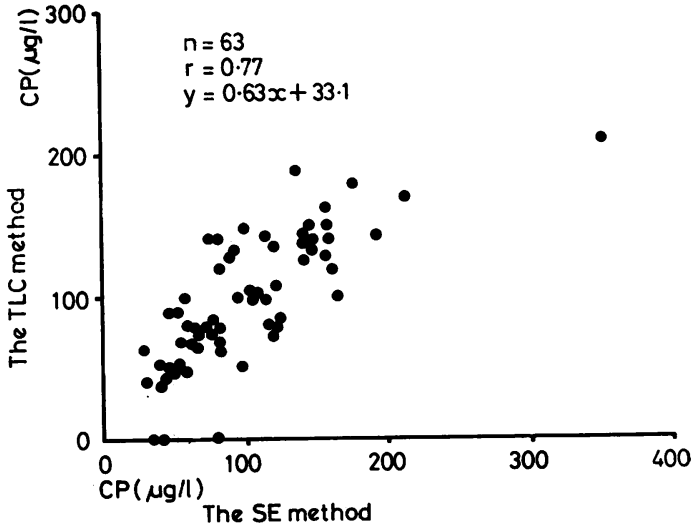

Fig. 4 Correlation between the SE and the TLC methods for estimating $C P$ in human urine.

the TLC method in Table 3, which also shows the results of CP determinations in rat urine. Table 4 shows the results of urinary $\mathrm{CP}$ determinations using the SE method, urinary lead determinations by an atomic absorption spectrophotometric method, and determinations of the levels of ALA dehydratase (ALAD) in blood by a method which measures the absorbency of porphobilinogen (Osanai, 1974).

\section{APPLICATION OF THE TLC METHOD}

Porphyrins in rat faeces and liver were determined by the TLC method. The results are shown in

Table 3 Comparison of the SE and the TLC methods

\begin{tabular}{|c|c|c|c|c|c|}
\hline Subjects & $N$ & $\begin{array}{l}\text { Urinary } C P(\mu g / l) \\
S E \text { method }\end{array}$ & $T L C$ method & $r^{*}$ & $\begin{array}{l}\text { Regression equation } \\
\text { constants }(y)\end{array}$ \\
\hline $\begin{array}{l}\text { Lead workers I } \\
\text { Lead workers II } \\
\text { Yusho patients } \\
\text { PCB-contaminated man (6 samples) } \\
\text { Controls } \\
\text { Total number of samples } \\
\text { Rats }\end{array}$ & $\begin{array}{r}20 \\
6 \\
21 \\
6 \\
10 \\
63 \\
13\end{array}$ & $\begin{aligned} 123 & \pm 45^{* *} \\
100 & \pm 124 \\
91 & \pm 41 \\
107 & \pm 56 \\
93 & \pm 36 \\
104 & \pm 55 \\
163 & \pm 73\end{aligned}$ & $\begin{aligned} & 113 \pm 47^{* *} \\
& 80 \pm 65 \\
& 102 \pm 33 \\
& 80 \pm 63 \\
& 87 \pm 42 \\
& 99 \pm 46 \\
& 188 \pm 89\end{aligned}$ & $\begin{array}{l}0.74 \\
0.99 \\
0.76 \\
0.80 \\
0.71 \\
0.77 \\
0.90\end{array}$ & $\begin{array}{l}0.75 x+20 \cdot 3 \\
0 \cdot 52 x+28 \cdot 2 \\
0.62 x+46 \cdot 3 \\
0.90 x-16.3 \\
0 \cdot 83 x+9 \cdot 6 \\
0.63 x+33 \cdot 1 \\
1 \cdot 13 x+4 \cdot 8\end{array}$ \\
\hline
\end{tabular}

*Correlation coefficient. $\quad * *$ Mean value \pm standard deviation.

Table 4 Tests for lead and CP in urine and ALAD in blood

\begin{tabular}{|c|c|c|c|}
\hline \multirow{2}{*}{ Subjects } & \multicolumn{2}{|l|}{ Urine } & \multirow{2}{*}{$\begin{array}{l}\text { Blood } \\
\text { ALAD }\left(10^{3} \text { OD/Ht }\right)^{*}\end{array}$} \\
\hline & $C P+(\mu g / l)$ & $P b \ddagger(\mu g / l)$ & \\
\hline
\end{tabular}

†Solvent extraction method described in this paper.

¥Atomic absorption spectrophotometry.

*Osanai's method (1974) modifying that of Bonsignore et al. (1965) which measures the absorbency of porphobilinogen formed. The activity is

then calculated using the formula: Activity $=\frac{[\text { Optical density }]_{558}}{\text { Haematocrit }} \times 10^{3}$.

**Mean value \pm standard deviation. 
Table 5, which also shows results obtained from human urine. One of the advantages of the TLC method was that substances other than CP, UP, and PP could be detected on a thin-layer plate. For example, a greenish fluorescence $(R f=0 \cdot 71)$, a yellowish fluorescence $(R f=0.82)$, and a green pigment $(\mathrm{Rf}=0.67)$ were detected in urine from patients (see Table 5, Nos. 5 and 6).

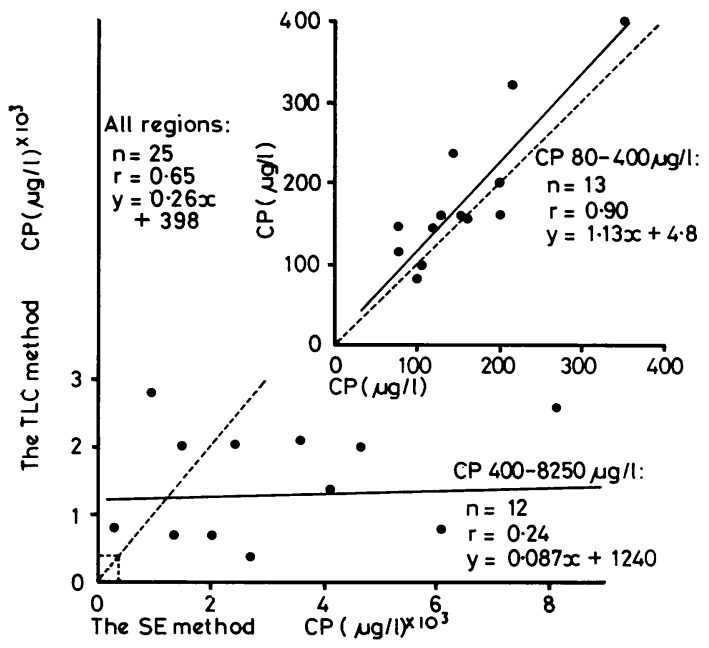

Fig. 5 Correlation between the SE and the TLC methods for estimating $C P$ in rat urine.

\section{Discussion}

For the TLC method to be successful it is essential to prepare a uniform thin layer, and to spot the sample properly. Truly white, mobile powdered talc with a tapping bulk density of less than $0.5 \mathrm{~g} / \mathrm{ml}$ must be used (Table 1).

Purdy and Truter (1962) investigated the development of phenylazo-2-naphthol in methanol by means of both the variable-volume single-drop technique and the constant-volume technique. They showed that a larger spot area is obtained by the latter than by the former technique and that the square root of the area is a linear function of the logarithm of the weight of the material in the spot. Our experimental results agreed approximately with these findings. We also found that the area is a linear function of the weight of porphyrins in the spot when low concentrations of porphyrins are estimated. This method gives the best results with porphyrin levels of $100-400 \mu \mathrm{g} / 1$. If porphyrin levels are higher than $400 \mu \mathrm{g} / \mathrm{l}$, it is necessary to dilute the sample with water.

The limit of detection of our TLC method was $1 \mathrm{ng}$, and it was not necessary either to heat-activate the thin-layer plate or to saturate the chamber with solvent vapour before the run. The plates are stable enough to be stored for several months at room temperature. Non-treated urine can be used in this method because porphyrinogens are photo-oxidised to porphyrins by fluorescent light radiation during the procedure. Standard solutions of porphyrins are fairly stable: we found that the porphyrin concentration in a $0 \cdot 1 \mathrm{~N} \mathrm{HCl}$ solution decreased gradually in a refrigerator maintained at $2^{\circ} \mathrm{C}$, but the monthly rate of decrease was less than $10 \mu \mathrm{g} / \mathrm{l}$.

In rat urine there was good correlation between the SE and the TLC methods $(r=0.90)$ for CP levels up to $400 \mu \mathrm{g} / \mathrm{l}$, but poor correlation $(\mathrm{r}=0.24)$ for levels over $400 \mu \mathrm{g} / \mathrm{l}$. According to Pinelli and Gaspari (1972) the solvent extraction method gives erroneously high porphyrin values because a yellow pigment, which Cardinal et al. (1968) isolated from porphyric urine, coexists with CP. Mori et al. (1969) found that a red-orange pigment with two strong absorption peaks near 490 and $400 \mathrm{~nm}$ was present in the urine extracts when $\mathrm{CP}$ was being determined. The presence of impurities also might cause inaccuracies. We have isolated a yellow pigment, which was present in both fresh and preserved urine, with greenish fluorescence and an $\mathrm{Rf}$ value of 0.71 , and have measured its u.v. absorption: it has a maximum

Table 5 Determinations by the TLC method

\begin{tabular}{|c|c|c|c|c|c|}
\hline Sample No. & Source & $U P$ & $\boldsymbol{C P}$ & $\boldsymbol{P P}$ & Notes \\
\hline 1 & Normal human urine 1 & $60 \mu \mathrm{g} / \mathrm{l}$ & $95 \mu \mathrm{g} / \mathrm{l}$ & - & $\left\{\begin{array}{l}\text { Two reddish spots were detected between } \\
\text { UP and CP }\end{array}\right.$ \\
\hline 2 & Normal human urine 2 & - & 70 & - & \\
\hline 3 & Normal human urine 3 & - & 45 & $一$ & \\
\hline 4 & Normal human urine 4 & - & 83 & - & Two reddish spots were seen over CP \\
\hline 5 & Patient urine 1 & 800 & 100 & - & Greenish fluorescence seen at $\mathrm{Rf} 0.71$ \\
\hline 6 & Patient urine 2 & 2300 & 740 & - & $\left\{\begin{array}{l}\text { Greenish pigments seen at } \mathrm{Rf} 0.67 \text { under } \\
\text { visible light }\end{array}\right.$ \\
\hline 7 & ${ }^{1}$ Rat urine & - & 2100 & - & One reddish spot detected at $\mathrm{Rf} 0.43$ \\
\hline 8 & Rat faeces & - & $13 \cdot 2^{\mu g}$ & $123 \mu \sigma$ & Faeces wt. $3 \cdot 3 \mathrm{~g} /$ day \\
\hline 9 & Rat liver & $29 \cdot 2^{\mu g}$ & - & - & Liver wt. (wet) $8 \cdot 2 \mathrm{~g}$ \\
\hline
\end{tabular}

${ }^{1}$ The rat was fed with the diet fortified with polychlorinated biphenyls (PCB) for 4 months, and killed after starvation for 24 h 
absorption at $490 \mathrm{~nm}$ but none at $400 \mathrm{~nm}$. This indicates that the material which gave a high $\mathrm{CP}$ value differs from the green fluorescent pigment that we isolated.

The CP value in normal urine was $87 \pm 42 \mu \mathrm{g} / 1$ (Table 3), which is reasonable if the upper limit is about $100 \mu \mathrm{g} / \mathrm{l}$.

The authors wish to thank Dr T. K. With of Svendborg County Hospital, Denmark, and Professor H. Miura of Kumamoto University School of Medicine, Japan, for their useful advice.

\section{References}

Bonsignore, D., Calissano, P., and Cartasegna, C. (1965). Un semplice metodo per la determinazione della $\delta$-aminolevulinico-deidratasi nel sangue. Medicina del Lavoro, 56, 199-205.

Cardinal, R. A., Bossenmaier, I., Petryka, Z. J., Johnson, L., and Watson, C. J. (1968). Isolation of porphyrins from porphyria urine by preparative thin-layer chromatography. Journal of Chromatography, 38, 100-105.

Katsuki, S. (1969). Report of the Kyushu University Study Group on 'Yusho'. Fukuoka Acta Medica, 60, 403-553.

Mori, M., Kurihara, M., Tokunaga, R., and Sano, S. (1969). Studies on determination of coproporphyrin in urine. Japanese Journal of Hygiene, 24, 137.

Osanai, H. (1974). In Handbook of Occupational Health, p. 804. Edited by T. Miura. The Institute for Science of Labour: Tokyo.

Pinelli, A., and Gaspari, R. (1972). A new precise and sensitive method for the assay of urine porphyrins using combined thin-layer chromatography and spectrophotofluorimetric analysis. Clinica Chimica Acta, 39, 135-142.

Purdy, S. J., and Truter, E. V. (1962). Quantitative analysis by thin-film chromatography. Analyst, 87, 802-809.

Rimington, C. (1960). Spectral-absorption coefficients of some porphyrins in the Soret-band region. Biochemical Journal, 75, 620-623.

Sano, S., and Granick, S. (1961). Mitochondrial coproporphyrinogen oxidase and protoporphyrin formation. Journal of Biological Chemistry, 236, 1173-1180.

With, T. K. (1969). Thin-layer chromatography of free and esterified porphyrins on talc. Journal of Chromatography, 42, 389-395. 